\title{
Tpit determines alternate fates during pituitary cell differentiation
}

\author{
Anne-Marie Pulichino, Sophie Vallette-Kasic, Judy Peih-Ying Tsai, Catherine Couture, \\ Yves Gauthier, and Jacques Drouin ${ }^{1}$ \\ Laboratoire de Génétique moléculaire, Institut de recherches cliniques de Montréal (IRCM), Montréal QC Canada H2W 1R7
}

\begin{abstract}
The T-box transcription factor Tpit was identified as a cell-specific factor for expression of the pituitary proopiomelanocortin (POMC) gene. Expression of this factor is exclusively restricted to the pituitary POMC-expressing lineages, the corticotrophs and melanotrophs. We have now determined the role of this factor in pituitary cell differentiation. Tpit is a positive regulator for late POMC cell differentiation and POMC expression, but it is not essential for lineage commitment. The pituitary intermediate lobe normally contains only Tpit-expressing melanotrophs. Inactivation of the Tpit gene results in almost complete loss of POMC-expressing cells in this tissue, which now has a large number of gonadotrophs and a few clusters of Pit-1-independent thyrotrophs. The role of Tpit as a negative regulator of gonadotroph differentiation was confirmed in transgenic gain-of-function experiments. One mechanism to account for the negative role of Tpit in differentiation may be trans-repression between Tpit and the gonadotroph-restricted factor SF1. These data suggest that antagonism between Tpit and SF1 may play a role in establishment of POMC and gonadotroph lineages and that these lineages may arise from common precursors.
\end{abstract}

[Keywords: T-box; pituitary development; transcription factor; POMC; gonadotropin; trans-repression; Tbx19]

Received December 9, 2002; revised version accepted January 27, 2003.

The pituitary gland is a very convenient model to study mechanisms of cellular differentiation. It has been particularly informative through identification of regulatory factors and their molecular mechanisms of action on organogenesis, as well as on cell differentiation and gene transcription. The pituitary gland is of dual embryonic origin and arises through intimate association of neural and oral roof ectoderm (Sheng and Westphal 1999). The mature pituitary gland of rodents is ultimately composed of three lobes. The posterior lobe, containing axonal projections emanating from the hypothalamus, is derived from neural ectoderm. The anterior and intermediate lobes are derived from a midline invagination of the oral ectoderm, Rathke's pouch, and contain the six hormone-secreting cell types: thyrotrophs producing thyrotropin (TSH), somatotrophs producing growth hormone $(\mathrm{GH})$, lactotrophs producing prolactin $(\mathrm{PRL})$, gonadotrophs producing gonadotropins (LH, FSH), melanotrophs producing $\alpha$-melanotropin $(\alpha \mathrm{MSH})$, and corticotrophs producing adrenocorticotropin (ACTH). ACTH and $\alpha \mathrm{MSH}$ are both processed from the same precursor, proopiomelanocortin (POMC). There are thus two separate lineages expressing the unique POMC gene; this expression is differentially controlled in each lin-

${ }^{1}$ Corresponding author.

E-MAIL drouinj@ircm.qc.ca; FAX (514)987-5575.

Article published online ahead of print. Article and publication date are at http://www.genesdev.org/cgi/doi/10.1101/gad.1065703. eage (Drouin et al. 1990). Whereas the melanotrophs constitute all the secreting cells of the intermediate lobe (IL), the corticotrophs represent about $5 \%$ of anterior lobe $(\mathrm{AL})$ cells in the adult rodent. Despite intensive investigation and identification of a number of cell-restricted transcription factors that play essential roles in specific lineages, the precursor/progeny relationships between these lineages are not yet clear.

During organogenesis, the developing pituitary maintains intimate contact with neural tissues of the ventral diencephalon, which produce signaling molecules important for pituitary differentiation and proliferation (Daikoku et al. 1982; Takuma et al. 1998). Bone morphogenic protein 4 (BMP4) and fibroblast growth factor 8 (FGF8) are expressed sequentially in the ventral diencephalon directly overlying Rathke's pouch (Ericson et al. 1998; Treier et al. 1998). BMP4 expression is detected as early as embryonic day 8.5 (E8.5) and precedes that of FGF8. These signals were shown to be important for the initial inductive phase of pituitary development and proliferation. In addition, sonic hedgehog (Shh) is expressed throughout the oral ectoderm except in Rathke's pouch, and was shown to be important for pituitary proliferation and patterning (Treier et al. 2001). These signaling molecules appear to influence expression of transcription factors essential for pituitary lineage differentiation, but their specific contribution to the differentiation process remains unclear.

Various cell-restricted transcription factors have been implicated in pituitary cell differentiation. The somato- 
lactotroph and thyrotroph lineages require Prop1 and Pit-1 for their differentiation (Bodner et al. 1988; Ingraham et al. 1988; Sornson et al. 1996). In gonadotrophs, GATA-2 and SF1 play positive roles in activation of gonadotroph-specific genes, and they are required for terminal differentiation (Ingraham et al. 1994; Steger et al. 1994; Dasen et al. 1999; Zhao et al. 2001). Some factors may also play negative roles in the differentiation process. At high levels of expression in the presumptive gonadotrophs, GATA-2 may inhibit Pit-1 expression but not at lower levels in thyrotrophs, where both Pit-1 and GATA-2 are coexpressed and important for activation of thyrotroph-specific genes (Dasen et al. 1999). Pit-1 may also have a negative role in thyrotrophs, where it prevents GATA-2 binding to gonadotroph-specific promoters (Dasen et al. 1999). These experiments have suggested mutually antagonistic roles for GATA-2 and Pit-1 in the gonadotroph and thyrotroph lineages, but it is not yet clear whether these two lineages arise from a common and unique precursor pool, because in mice deficient for these factors, the fate of these lineages have not been observed to change.

The relationship of POMC-expressing lineages with other pituitary cell types is still unclear, particularly because knockout of genes such as Lhx3 and Pitx2, involved in early pituitary organogenesis, prevents differentiation of all lineages except corticotrophs (Sheng et al. 1996; Gage et al. 1999; Lin et al. 1999). Two transcription factors have been identified thus far and were shown to be restricted to corticotrophs and/or melanotrophs in the pituitary: NeuroD1 in corticotroph (Poulin et al. 1997, 2000) and Tpit (Tbx19) in both POMC lineages (Lamolet et al. 2001). Because all pituitary cells appear to have a common origin in Rathke's pouch, relationships must exist between the different lineages, and some regulatory genes must play crucial roles in cell fate decisions. The present work reveals a positive role of Tpit in the POMC lineage as well as a negative role of the same factor to prevent gonadotroph and Pit-1-independent thyrotroph differentiation. Indeed, intermediate lobe cells destined to become melanotrophs mostly differentiate into gonadotrophs in Tpit-deficient mice. These findings implicate Tpit as a major regulatory gene for establishment of cell fate between POMC and gonadotroph lineages.

\section{Results}

The Tpit transcription factor is a T-box factor cloned for its interaction with Pitx1 on the POMC promoter (Lamolet et al. 2001). Its expression is restricted to the POMC lineages of the pituitary. It is sufficient for $P O M C$ gene activation in undifferentiated pituitary cells in gain-of-function transgenic mice, suggesting a role of Tpit in POMC cell differentiation. To better understand the role of Tpit during pituitary development, we produced Tpit-null mice by deleting most of Tpit's T-box coding sequences. LacZ coding sequences were fused inframe with the remaining Tpit coding sequences (Fig.

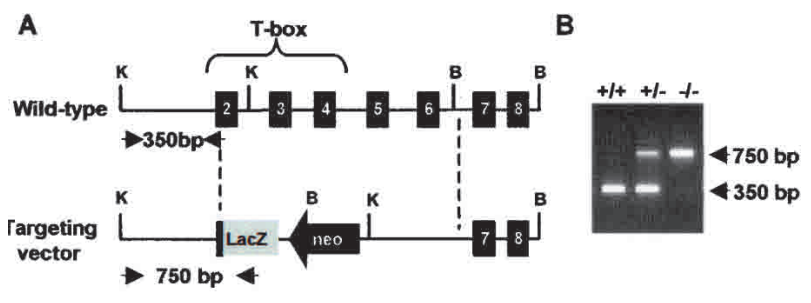

C
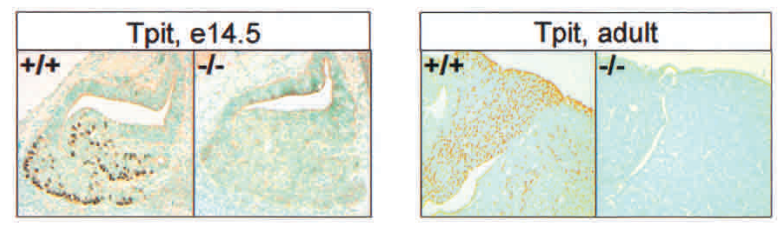

D

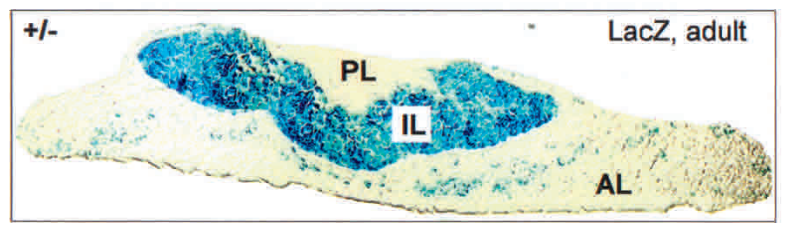

Figure 1. Targeted disruption of the mouse Tpit gene. $(A)$ Homologous recombination between the mouse Tpit gene (top) and the targeting vector (bottom) will result in replacement of almost all of the coding region by a lacZ coding gene. $\mathrm{K}, \mathrm{KpnI}$; B, BamHI. (B) PCR assay for genotyping using oligonucleotides identified by arrows in $A$. Wild-type and Tpit-/- PCR products are 350 and $750 \mathrm{bp}$, respectively. (C) Tpit immunohistochemical analysis of pituitaries from wild-type and Tpit-/- mice showing absence of Tpit protein in E14.5 mutant embryo and adult. $(D)$ LacZ staining of pituitary from Tpit+/- mouse showing expression of $\beta$-galactosidase throughout intermediate lobe (IL) melanotroph cells and in a subset of anterior lobe (AL) cells (corticotrophs), whereas no expression is detected in posterior lobe $(\mathrm{PL})$.

1A). Using this targeting vector, two independent mouse mutant lines were derived (Fig. 1B). Both lines were bred with Balb/c and 129sv mice and, in each case, homozygous mutant mice were viable and fertile. Similar results were obtained in both genetic backgrounds (data not shown). Absence of pituitary Tpit expression was confirmed in Tpit-/- mice by immunohistochemistry (Fig. 1C). In Tpit+/- mice, lacZ-expressing cells were restricted to POMC cells of the AL and IL (Fig. 1D) and were not present in other POMC-expressing tissues, such as skin or hypothalamic POMC neurons (data not shown), in agreement with the highly pituitary-specific expression of Tpit (Lamolet et al. 2001).

Tpit is required for late POMC lineage differentiation but not for lineage commitment

The developing pituitary of Tpit-null mice (E14.5) has apparently normal histology (Fig. 2A). However, the number of POMC-positive cells is greatly reduced, with only a few cells remaining. The great reduction in 
Pulichino et al.

A

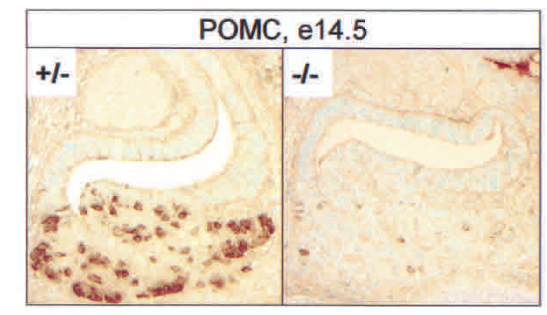

D

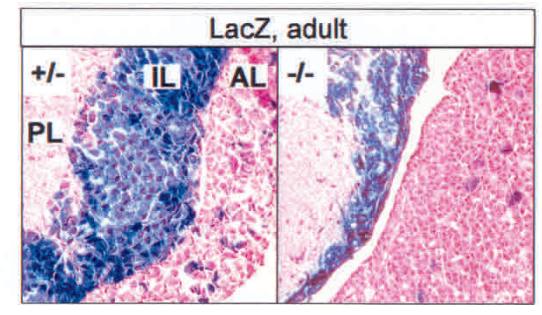

B

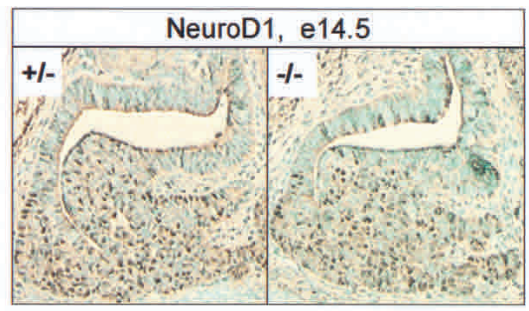

E

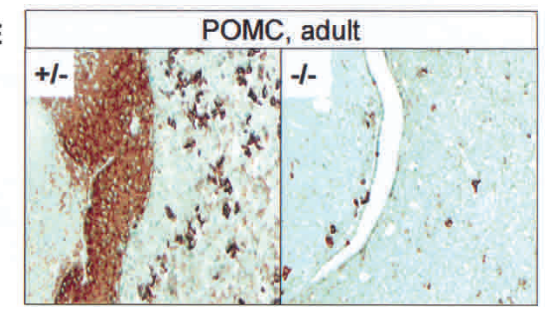

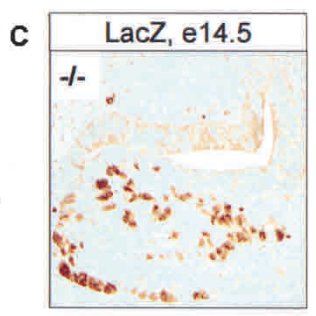

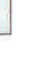


A
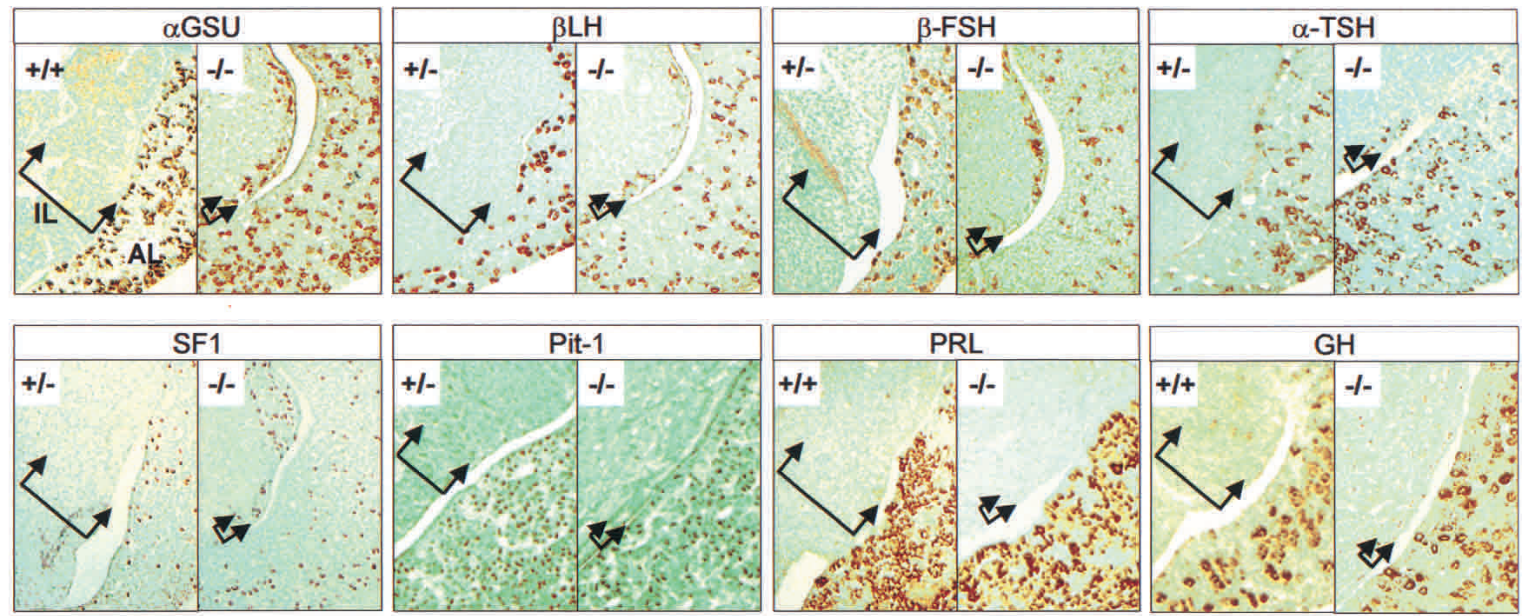

B

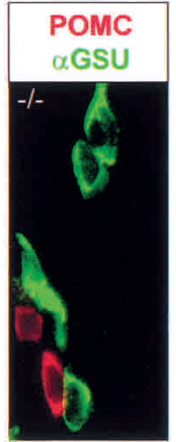

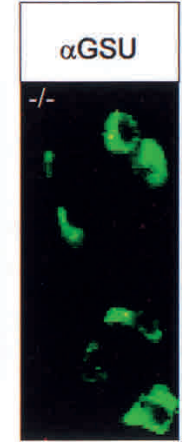
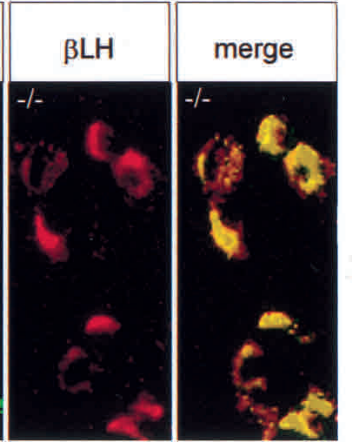

C
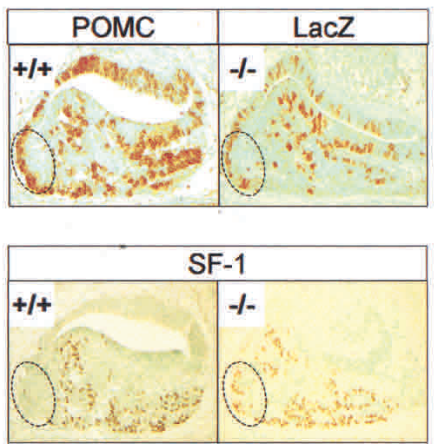

Figure 3. Alternate pituitary cell fates in the absence of Tpit. The hypoplastic intermediate lobe (IL, bracketed by arrows) of Tpit-/pituitaries contains gonadotroph and Pit-1-independent thyrotroph cells in addition to the few POMC-positive cells (Fig. 2E). (A) Gonadotroph cells are revealed using immunohistochemical analysis for $\alpha$ GSU, $\beta L H, \beta F S H$, and SF1. Thyrotrophs are revealed using anti-TSH antibody. Very few TSH-positive clusters were present in all mutant pituitaries examined. Pit-1 immunoreactivity was never detected in hypoplastic IL, including in sections adjacent to TSH-positive cell clusters. PRL and GH were never detected in hypoplastic IL. $(B)$ Colocalization immunohistochemistry indicates that hypoplastic IL cells are either POMC lineage or gonadotroph. Colabeling with POMC and $\alpha$ GSU never showed any cells positive for both. Colocalization between $\alpha$ GSU and $\beta$ LH showed all $\beta$ LH cells to be $\alpha$ GSU-positive. (C) Ectopic expression of SF1 in AL of E16.5 Tpit-/- pituitaries. The dotted area represents a cluster of POMC-positive cells usually observed on the ventrocaudal side of normal $(+/+)$ E16.5 pituitaries. A similar pattern of lacZ-positive cells was observed in Tpit-/- pituitary. This area is usually devoid of SF1-positive cells in normal $(+/+)$ pituitaries, but Tpit-/- pituitaries exhibit SF1-positive cells in this area.

Pit-1, and no Pit-1 was detected in the hypoplastic IL of Tpit-/- mice, including in sections consecutive to those where $\beta$ TSH expression was shown. The absence of Pit-1 in these later cells indicates that the thyrotrophs in the hypoplastic Tpit-/- IL are similar to the Pit-1-independent lineage.

To investigate whether the $\beta \mathrm{LH}$ and $\beta \mathrm{FSH}$-positive cells in the hypoplastic IL are gonadotrophs, we assessed the expression of a marker of normal gonadotroph differentiation, SF1, an orphan nuclear receptor that plays essential roles at multiple levels of the reproductive axis (Parker and Schimmer 1997). The large number of SF1positive cells in the Tpit-/- IL supports the idea that these cells are bona fide gonadotrophs (Fig. 3A). Colocalization experiments showed that Tpit-/- IL cells express POMC or $\alpha \mathrm{GSU}$, never both, and that $\alpha \mathrm{GSU}$ and $\beta \mathrm{LH}$ expression colocalize (Fig. 3B). These colocalization experiments are in agreement with the conclusion that, in the absence of Tpit, cells of the IL predominantly differentiate into gonadotrophs together with a few melanotrophs and Pit-1-independent thyrotrophs, and that they do not appear to have a mixed or abnormal cell identity. Because all of the cells of the Tpit-/- IL express the $\beta$-gal gene inserted in the Tpit locus, these data clearly support the interpretation that cells originally destined to become melanotrophs have instead differentiated into gonadotrophs or Pit-1-independent thyrotrophs.

We analyzed E16.5 embryos to determine whether cell fate changes also occur in the AL. Indeed, pituitary cells normally expressing POMC in the caudal part of wildtype mice now express both lacZ and SF1 in the Tpit-/mice (Fig. 3C). At this early developmental timepoint, this caudal part of the pituitary does not normally have SF1- or glycoprotein hormone-expressing cells. These correlative observations suggest that cell fate changes 
Pulichino et al.

between corticotrophs and gonadotrophs may also occur in the AL of Tpit-/- mice.

\section{Tpit is a repressor of the gonadotroph lineage}

The appearance of gonadotroph and Pit-1-independent thyrotroph cells in the IL of Tpit-/- mice might reflect a default differentiation pathway, and/or it may be suggestive of a Tpit activity as a repressor of the gonadotroph lineage. To better assess these possibilities, we designed a gain-of-function experiment in transgenic mice using the $\alpha$ GSU promoter to drive Tpit expression in the gonadotroph lineage (Fig. 4). The pituitaries of these mice have slightly more Tpit-positive (Fig. 4A) and POMCpositive cells (Fig. 4B) in the AL. The number of $\alpha$ GSUpositive cells is reduced (Fig. 4C), whereas $\beta$ TSH-positive cells are present in normal number (Fig. 4D). Most strikingly, $\beta \mathrm{LH}$ is no longer detectable in transgenic pituitaries (Fig. 4E), whereas the level of $\beta F S H$ is greatly reduced (Fig. 4F). $\alpha$ GSU-Tpit pituitaries also have less SF1-positive cells, and the remaining SF1-positive cells (mostly on the ventral side of the gland) express low SF1 levels (Fig. 4G). The use of the $\alpha \mathrm{GSU}$ promoter in this experiment is a limiting factor, because it appears that its expression is itself subject to Tpit repression. Taken together, these results indicate that Tpit represses at least late events of gonadotroph differentiation as assessed by hormone and SF1 expression.

\section{Trans-repression of Tpit and SF1 activity}

Tpit may repress the gonadotroph phenotype by different mechanisms. In view of the decreased expression of SF1 and of SF1-dependent genes such as $\beta \mathrm{LH}$ (Halvorson et al. 1996, 1998; Tremblay and Drouin 1999; Tremblay et al. 1999), we investigated the possibility of a transcriptional interaction between Tpit and SF1. Using an SF1dependent reporter in $\alpha \mathrm{T} 3$ cells that express endogenous SF1, we found that increasing amounts of Tpit antagonized SF1-dependent transcriptional activity (Fig. 5A). Conversely, Tpit-dependent activity of a reporter containing the Tpit/Pitx target sequence (Lamolet et al. 2001) was reversed in the presence of increasing amounts of SF1 (Fig. 5B). Mutual trans-repression by these two transcription factors is thus one mechanism by which they may influence differentiation of pituitary precursors and expression of cell-specific target genes. Transrepression is the reciprocal antagonism of transcription produced through protein-protein interactions between two activators of transcription. On a given target gene, DNA binding activity is only required for the activating factor but not for the repressing one. This mechanism of repression was best characterized for GR and AP-1 (Yang-Yen et al. 1990), GR and NFk-B (Ray and Prefontaine 1994; Scheinman et al. 1995), and for GR and NFGI-B (Philips et al. 1997). In support of this mode of action, we used the I171T Tpit mutant that has lost DNA binding activity (Pulichino et al. 2003) to show

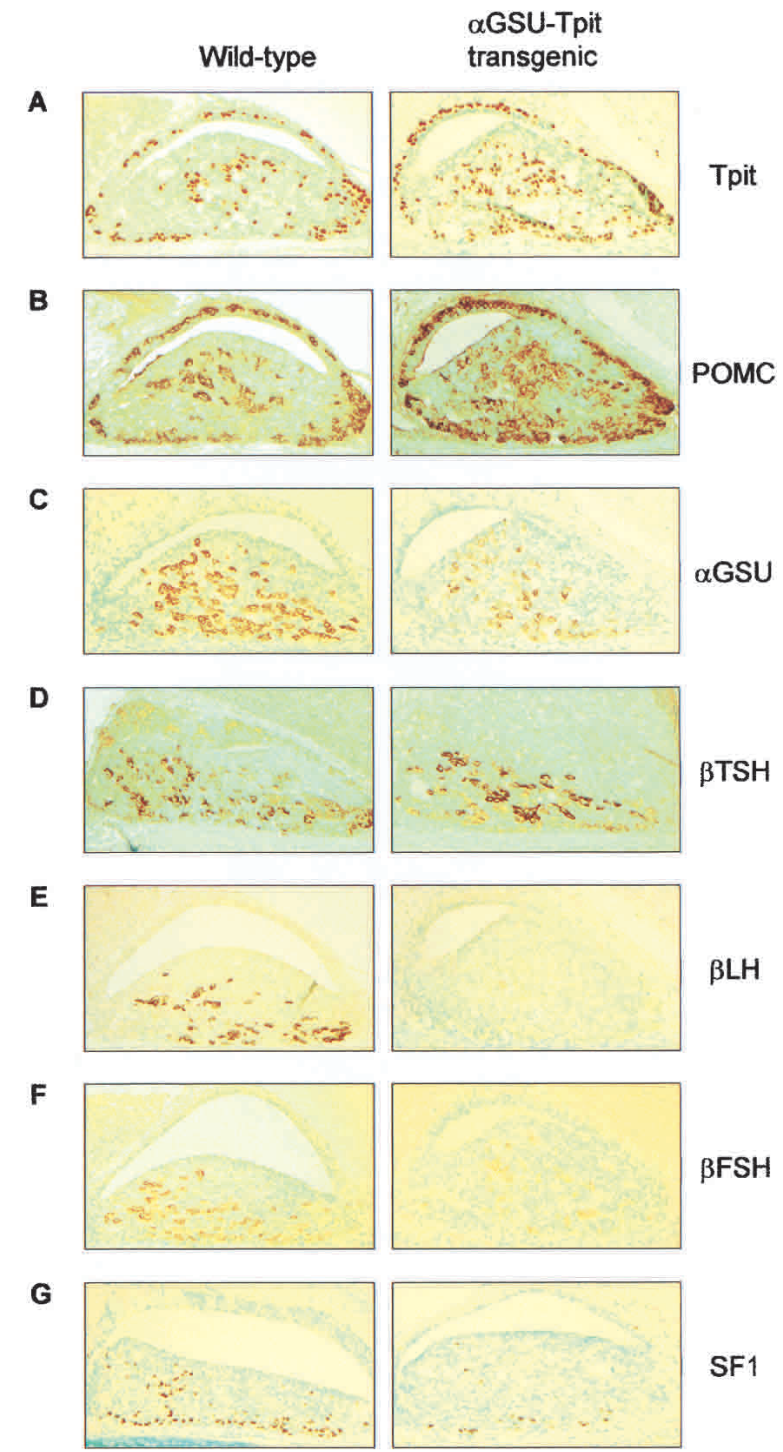

Figure 4. Repression of gonadotroph differentiation in transgenic mice expressing Tpit under control of $\alpha$ GSU promoter. Expression of marker genes was assessed by immunohistochemistry on sections of pituitaries from wild-type or transgenic mice (four transgenics showed a similar phenotype). A slight increase in the number of anterior lobe (AL) Tpit-positive $(A)$ and POMC-positive $(B)$ cells is observed in transgenic pituitary, whereas a decrease of $\alpha \mathrm{GSU}(C)$ and $\beta F S H(F)$ expression is observed. LH $\beta$ is no longer detectable $(E)$, whereas $\beta$ TSH $(D)$ expression appears to be relatively normal. The number of SF1positive cells $(G)$ is decreased in the transgenic pituitaries.

Tpit repression of SF1 activity even in absence of DNA binding by Tpit (Fig. 5C). We also observed in pull-down assays that the two proteins interact directly in vitro (Fig. 5D). In addition, Tpit may directly repress the expression of gonadotroph-specific genes, and this could be shown for the $\alpha$ GSU promoter (Fig. 5C). In similar transfection experiments, the available $\beta \mathrm{LH}, \beta \mathrm{FSH}, \beta \mathrm{TSH}$, GH, and PRL promoter constructs (Tremblay et al. 1998) were not affected by Tpit (data not shown). Also, the available mouse SF1 promoter was not found to be af- 
A SF1-RE-LuC

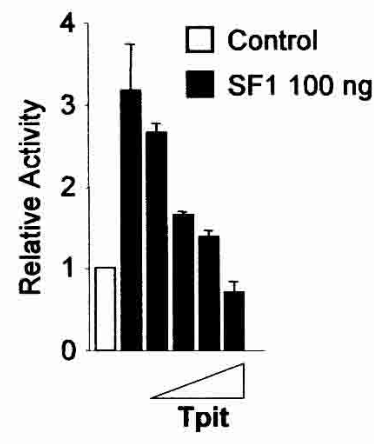

C SF1-RE-LUC

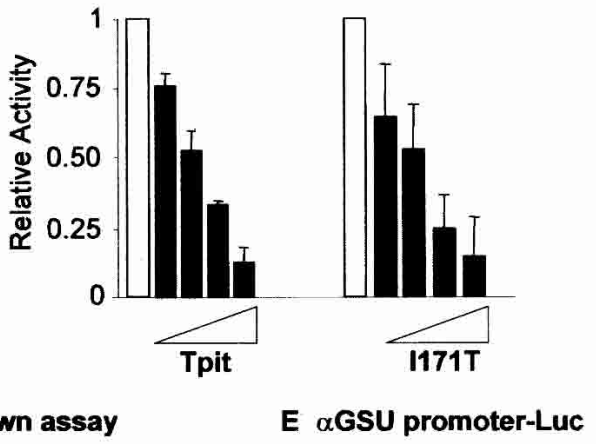

SF1

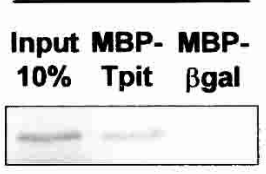

B TpitPitx-RE-Luc

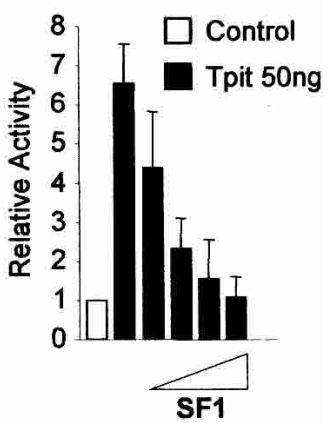

of the undetectable $\beta \mathrm{LH}$ expression in the $\alpha$ GSU-Tpit transgenic mice (Fig. 4E), these negative transfection results may reflect the absence of relevant regulatory sequences in the available promoter constructs. Another cell-specific regulator of gonadotroph differentiation is GATA-2 (Steger et al. 1994; Dasen et al. 1999). In similar transfection experiments using either the mouse GATA-2 promoter or a reporter dependent on tandemly repeated GATA sites, we could not detect any effect of Tpit on GATA-dependent transcription /data not shown). These results suggest that Tpit-dependent transrepression is restricted to SF1 and is not exerted on the other gonadotroph-specific factor GATA-2.

\section{Discussion}

The role of Tpit as a positive regulator of differentiation for both pituitary POMC lineages is very consistent with the highly cell-restricted expression of this factor. Conversely, the absence of Tpit in other adult pituitary lineages did not suggest a role of this factor in these lineages: the discovery of its role as negative regulator of gonadotroph differentiation is therefore surprising. The present work thus defines previously unknown relationships among four pituitary lineages, namely melanotrophs, corticotrophs, gonadotrophs, and the transient population of Pit-1-independent thyrotrophs. These lineages are thus clearly demarcated relative to the other three pituitary lineages which are Pit-1-dependent, namely the somatotrophs, lactotrophs, and Pit-1-dependent thyrotrophs. In this context, we propose a scheme for pituitary cell differentiation that is divided into two alternate pathways (Fig. 6).

\section{Tpit is a positive regulator in POMC-expressing cells}

Tpit was identified as a cell-specific transcription factor of the POMC gene. Its role in this context is entirely dependent on Pitxl (Lamolet et al. 2001), and the bHLH factor NeuroD1/Beta2 also plays a crucial role for promoter activity (Poulin et al. 2000). We have now shown that Tpit is very important for the last step of corticotroph differentiation, namely POMC gene expression (Fig. 2A,E). However, the AL of Tpit-/- pituitaries contains an about normal number of lacZ-positive (Fig. 2C) and NeuroD1-positive (Fig. 2B) cells at E14.5, and the IL is normally formed in these pituitaries (Fig. 2A-C). These data indicate that corticotroph precursors, pre-corticotrophs, form in apparently normal number in the absence of Tpit. Thus, Tpit is not essential for commitment of POMC lineages.

In addition to its role in late differentiation of corticotrophs and melanotrophs revealed through failure of POMC expression, the role of Tpit in the maintenance of those cells is highlighted by the present findings. Indeed, adult pituitaries of Tpit-/- mice have very few POMCpositive and lacZ-positive cells remaining in the AL (Fig. 2D,E). Also, the IL is hypoplastic, with only a few POMC-expressing melanotrophs (Fig. 2D,E). Because the

fected by Tpit; it is however noteworthy that a 50-kb SF promoter fragment was recently shown to be insufficient for gonadotroph expression (Stallings et al. 2002). In view 


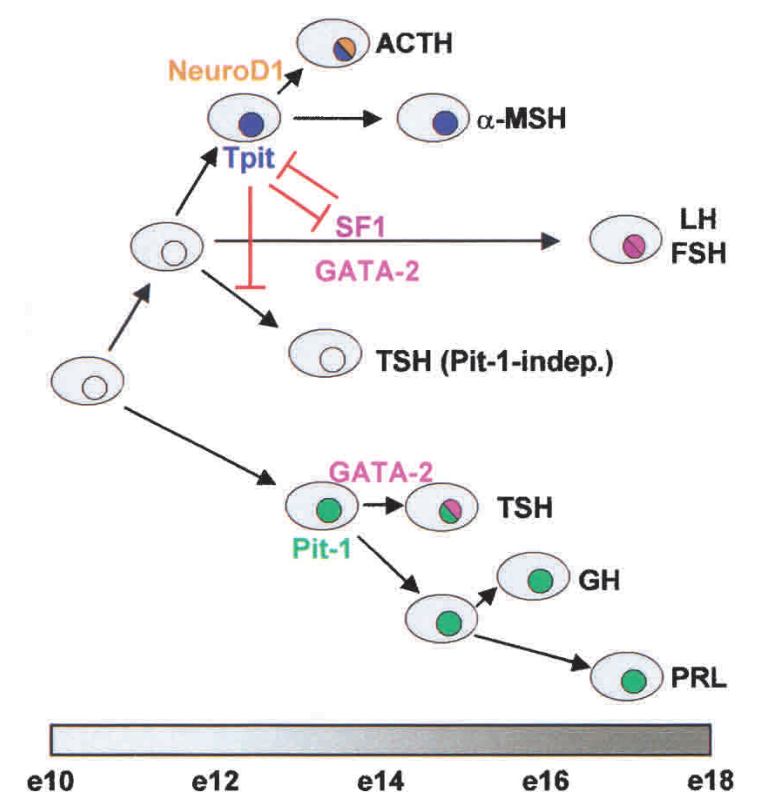

Figure 6. A binary model of pituitary cell differentiation. The present work provides support for a model of pituitary cell differentiation that relies on sequential choices between alternate fates. In this model, the cortico/melanotroph (ACTH, $\alpha \mathrm{MSH})$ and gonadotroph (LH, FSH) lineages arise from a common precursor (present work) that is different from precursors of Pit-1dependent lineages (GH, PRL, TSH). In the cortico/melano/gonadotroph lineage, expression of (and antagonism between) Tpit and SF1 establishes the POMC or gonadotroph lineage, respectively. In this branch of the pathway, GATA-2 contributes to the gonadotroph phenotype, whereas in the Pit-1-dependent branch of the pathway, it acts together with Pit-1 for differentiation of thyrotrophs (Dasen et al. 1999). The model is roughly aligned with a timeline of mouse pituitary development.

pituitary histology and abundance of pre-corticotrophs and pre-melanotrophs appear relatively normal at E14.5, it is likely that these cells do not proliferate between fetus and adult, or that they are lost during that period of growth. Irrespective of which of these two possibilities accounts for the deficit of melanotrophs and corticotrophs in adults, these observations indicate that Tpit has a role in maintenance of these cells.

\section{Tpit is a negative regulator of gonadotroph differentiation}

In the absence of Tpit, IL cells destined to differentiate into melanotrophs (lacZ-positive in Tpit-/- pituitaries) differentiate instead into gonadotrophs or Pit-1-independent thyrotrophs (Fig. 3A). These cells do not have mixed identity (Fig. 3B) and have the hallmarks of bona fide gonadotrophs or Pit-1-independent thyrotrophs. These data indicate that Tpit normally represses these differentiation pathways (Fig. 6). Transgenic gain-of-function experiments confirm this interpretation, because Tpit overexpression in gonadotrophs leads to extinction of $\beta \mathrm{LH}$ expression and to decreased expression of $\alpha \mathrm{GSU}$, $\beta F S H$, and SF1 (Fig. 4).
The change of IL cell fate suggests that similar pathways may be implicated in cortico/melanotroph and in gonadotroph differentiation in both the IL and AL. A specific signal for cortico/melanotroph differentiation may trigger this program through activation of Tpit expression, whereas a competing signal may initiate gonadotroph differentiation by induction of SF1 expression. Antagonism between Tpit and SF1 ensures that once a cell has responded to one signal by expression of either Tpit or SF1, the expressed factor prevents action of the other. This antagonism establishes a unique program of gene expression and determines cell identity. This model implies that signals for cortico/melanotroph and gonadotroph differentiation operate on a common pool of precursor cells. These precursors have not yet been identified, and there are no markers to differentiate these from other precursors, such as those of the Pit-1-dependent somato-lactotroph and definitive thyrotroph lineages (Fig. 6).

The presence of a few Pit-1-independent thyrotrophs in the IL of Tpit-/- pituitaries suggests that this transient lineage is also related to the cortico/melanotroph and gonadotroph lineages. Appearance of these cells is not dependent on SF1 in the normal pituitary (Lin et al. 1994), and they also appear to be SF1-negative in Tpit-/pituitaries (data not shown). In both knockout and transgenic gain-of-functions, Tpit did not appear to affect the other thyrotroph lineage, that is, the definitive Pit-1-dependent thyrotrophs (Figs. 3A, 4B). These data clearly support previous models in which these two thyrotroph lineages have different origins (Lin et al. 1994).

Tpit action may repress the gonadotroph phenotype by different mechanisms. First, the nonoverlapping patterns of SF1 and Tpit expression suggest that the expression of both factors is mutually exclusive in vivo. Second, Tpit was shown to directly repress transcription of the $\alpha \mathrm{GSU}$ promoter (Fig. 5E), indicating that part of Tpit's repressor activity may be through direct action on gonadotrophspecific coding genes. Thirdly, we showed that Tpit and SF1 antagonize each other's activity on cognate reporters (Fig. 5A,B). This antagonism appears to result from a mechanism of trans-repression in which DNA binding activity is not required for the repressing factor (Fig. 5C) and which involves protein-protein interactions (Fig. 5D), as shown for other factors that antagonize each other's activity by trans-repression (Yang-Yen et al. 1990; Ray and Prefontaine 1994; Scheinman et al. 1995; Philips et al. 1997). In these examples of trans-repression that involve GR, the mechanism of trans-repression remains elusive, although recent work has revealed a unique pattern of CTD phosphorylation of RNA Polymerase II complexes that are paused as a result of trans-repression between GR and NFKB (Nissen and Yamamoto 2000). Trans-repression may not rest on recruitment of corepressors but may involve coactivators (Rogatsky et al. 2001). Although repressor domains have been identified in other T-box factors, such as Tbx2 and Tbx3 (Carreira et al. 1998; He et al. 1999), Tpit does not have sequences that are homologous to these domains. 


\section{A binary model of pituitary cell differentiation}

All pituitary cells differentiate from a common pool that originates in the epithelial folds of Rathke's pouch. The precise relationships among pituitary lineages are not yet clear, but a model of signal gradients has been proposed to account for differentiation of these lineages (Ericson et al. 1998; Treier et al. 1998). By providing evidence for a common precursor for both cortico/melanotroph and gonadotroph lineages and by demarcating these lineages in comparison to Pit-1-dependent lineages, the present work can be taken to support a binary model of pituitary cell differentiation (Fig. 6). Indeed, early pituitary precursors may initially choose, possibly under the influence of signaling gradients, either the cortico/melano/gonadotroph or Pit-1-dependent pathways. Next, cortico/melano/gonadotroph precursors will take either the cortico/melanotroph or gonadotroph path, depending on expression of Tpit or SF1, respectively. GATA-2 was shown to influence differentiation of one lineage in each branch of the differentiation pathway (Dasen et al. 1999). In the cortico/melano/gonadotroph pathway, it promotes gonadotroph differentiation (in combination with SF1), whereas in the Pit-1-dependent pathway, it acts together with Pit-1 for differentiation of definitive thyrotrophs. The absence of Pit-1-dependent cells in the IL of Tpit-/- mice taken together with the antagonistic actions of Tpit and SF1 clearly supports a model (Fig. 6) in which the initial binary choice is between Tpit and Pit-1-dependent lineages, with Tpit being expressed earlier than Pit-1 in the AL (Dolle et al. 1990; Lamolet et al. 2001). Secondary cell fate choices would then involve SF1 and/or GATA-2. For POMC lineages, NeuroD1 is important for corticotroph, but not melanotroph, differentiation (B. Lamolet, K. Chu, G. Poulin, F. Guillemot, M.J. Tsai, and J. Drouin, in prep.). NeuroD1 expression starts at E12 in corticotrophs (Poulin et al. 2000); that is, at the same time as Tpit (Lamolet et al. 2001), and NeuroD1 deficiency prevents POMC, but not Tpit, expression (B. Lamolet, K. Chu, G. Poulin, F. Guillemot, M.J. Tsai, and J. Drouin, in prep.). Thus, Tpit and NeuroD1 appear to be regulated in parallel and independently of each other, both being similarly required for terminal corticotroph differentiation and POMC expression.

The present work has provided the first evidence to demarcate the cortico/melanotroph and gonadotroph lineages in opposition to the Pit-1-dependent somatolactotrophs and definitive thyrotrophs. Taken together, our data support a model in which differentiation of pituitary cells is established through a series of binary choices that oppose each other and lead to establishment of lineage identity.

\section{Materials and methods}

\section{Gene targeting, transgenics, and genotyping}

The murine Tpit gene was cloned from a 129sv genomic library (gift from J.P. Julien, McGill University, Montréal, Quebec, Canada). To construct the targeting vector, a $4.3-\mathrm{kb}$ NcoI $/ \mathrm{KpnI}$ fragment containing part of intron 1 and exon 2 and a $2.7-\mathrm{kb}$ BamhI/Mscl fragment containing exons 7 and 8 were subcloned in pUC19 and used as $5^{\prime}$ and $3^{\prime}$ recombination targets. Tpit exons 3-6 were replaced by a pGKneo-pA cassette (gift from D. Lohnes, Clinical Research Institute of Montréal, Montréal, Quebec, Canada), and a lacZ coding gene was inserted in frame with exon 2, leaving seven amino acids of this exon. Mutant ES cell lines were obtained as described (Lanctôt et al. 1999). Homologous recombination occurred at the Tpit locus in 15 out of 480 transfectants that were picked. Two different ES cell clones were injected into blastocysts, and mouse lines were established for both. Tpit mutant animals were crossed with $129 \mathrm{sv}$ and Balb/c mice. All exhibited the same pituitary phenotype. ES cells lines and the first 50 mice were genotyped by genomic Southern blotting with $5^{\prime}$ and $3^{\prime}$ probes. Other mice were genotyped by PCR using DNA isolated from tails or umbilical cords. Transgenic mice were generated as described (Lamolet et al. 2001), and embryos were taken by caesarean section at E18.5.

Sections and lacZ staining

Paraffin sections were performed as described (Lanctôt et al. 1997). For lacZ staining, tissues were fixed in $4 \%$ paraformaldehyde (PFA) for $15 \mathrm{~min}$, rinsed with PBS, and stained overnight at $30^{\circ} \mathrm{C}$ in X-gal solution $\left(5 \mathrm{mM} \mathrm{K}_{3} \mathrm{Fe}(\mathrm{CN})_{6}, 5 \mathrm{mM} \mathrm{K}_{4} \mathrm{Fe}(\mathrm{CN})_{6}{ }^{\star}{ }^{3} \mathrm{H}_{2} \mathrm{O}\right.$, $1 \mathrm{~m} \mathrm{M} \mathrm{MgCl} 2,0.01 \%$ sodium desoxycholate, $0.02 \% \mathrm{NP}-40$, $0.1 \% \mathrm{X}$-gal), rinsed with PBS, and postfixed in $4 \%$ PFA.

\section{Cells and transfections}

$\alpha \mathrm{T} 3$ cells were cultured in Dulbecco's modified Eagle medium supplemented with $10 \%$ fetal calf serum and antibiotics; then 250,000 cells were transfected in 12-well dishes with Lipofectamine (Invitrogen) using $500 \mathrm{ng}$ reporter plasmid, up to a total of $1.5 \mu \mathrm{g}$ DNA per assay. Cells were harvested $48 \mathrm{~h}$ later.

\section{Pull-down assays}

All MBP fusion proteins were produced, and $\left[{ }^{35} \mathrm{~S}\right]$-labeled SF1 was synthesised in vitro as described (Batsche et al. 1998). Labeled proteins were incubated with $400 \mathrm{ng}$ immobilized MBP-lacZ or MBP-Tpit constructs in $150 \mu \mathrm{L}$ of TNEN50 (50 $\mathrm{mM}$ TRIS at $\mathrm{pH} 7.5,5 \mathrm{mM}$ EDTA, $50 \mathrm{mM} \mathrm{NaCl}, 0.1 \%$ NP-40) with $1 \mathrm{mM}$ PMSF and $2 \%$ BSA for $2 \mathrm{~h}$ at $4^{\circ} \mathrm{C}$. Beads were washed at $4^{\circ} \mathrm{C}$ twice in TNEN250 and twice in TNEN125. Bound proteins were resolved on SDS-PAGE, stained with Coomassie blue to ensure that similar amounts of fusion proteins were recovered, and then autoradiographed.

\section{Immunohistochemistry and immunofluorescence}

Immunohistochemistry was performed as described (Lanctôt et al. 1997). Antibodies were used as follows: rabbit anti-Tpit 1:200 (Lamolet et al. 2001), mouse anti-POMC 1:500 (Cortex Biochem), mouse anti-lacZ 1:500 (ICN Pharmaceuticals), rabbit anti-SF1 1:1500 (kind gift from K. Morohashi, National Institute for Basic Biology, Okazaki, Japan), rabbit anti-Pit-1 1:50 (Santa Cruz Biotechnology), rabbit anti- $\alpha$ GSU 1:500, rabbit anti- $\beta$ FSH $1: 200$, rabbit anti-prolactin 1:1000, rabbit anti-GH 1: 1670, guinea pig anti- $\beta$ LH 1:200 (all pituitary hormones antibodies were kindly provided by A.F. Parlow, Pituitary Hormones and Antisera Center, Torrance, CA). All secondary antibodies were used 1:150 (Vector Laboratories). NeuroD1 was detected with rabbit anti-NeuroD1 1:10 (Poulin et al. 2000) with the TSA biotin system (PerkinElmer Life Sciences). For immunofluores- 
cence, sections were treated as above. For $\alpha \mathrm{GSU} / \mathrm{POMC}$ colocalization, anti- $\alpha$ GSU was incubated overnight, mouse antiPOMC (1:200) and anti-rabbit-biotinylated (1:200, Vector) were added, and finally, anti-mouse-rhodamine (1:200, ImmunoPure Antibody) and avidin-fluorescein (1:200, Vector) were added. For $\alpha \mathrm{GSU} / \beta \mathrm{LH}$ colocalization, anti- $\beta \mathrm{LH}(1: 200)$ was incubated overnight, rabbit anti- $\alpha$ GSU $(1: 200)$ and anti-guinea pig-biotinylated (1:200, Vector) were added next, and then anti rabbitfluorescein (1:200, Vector) and avidin-rhodamine (1:200, Vector) were added. Sections were placed in blocking solution $15 \%$ dried skim milk in PBS, $0.2 \%$ Tween 20 ) between each step.

\section{Acknowledgments}

We thank Drs. Marc Therrien and Guy Sauvageau for critical comments on this manuscript. We are very grateful to Drs. K. Morohashi and A.F. Parlow of the NIH Pituitary Hormone Program for antibodies against SF1 and pituitary hormones, respectively. We thank Dr. Keith Parker for SF1 and SF1-RE plasmids; Dr. David Lohnes for targeting vectors; and Dr. David Gordon for the $\alpha$ GSU reporter plasmid. The 129sv genomic library was kindly provided by Drs. Jean-Pierre Julien and Janet Rossant, and ES R1 cells were a generous gift of Dr. Andras Nagy. Dr. Pamella Mellon kindly provided the $\alpha \mathrm{T} 3$ cells. We are most thankful to Dr. Qianzhang Zhu and Michel Robillard of the IRCM Transgenesis Service for production of Tpit knockout mouse lines and transgenic mice, to Ms. Annie Vallée of the IRCM Histology Laboratory for her expert assistance, and to Ms. Julie D'Amours for her help with animal husbandry. The unrelenting secretarial support of Lise Laroche is greatly appreciated. A.M.P. was supported by a studentship from Canadian Institutes of Health Research, and S.V.K. by a Bourse d'études internationales de l'Institut Lilly and A.DE.RE.M. This work was supported by the National Cancer Institute of Canada with funds provided by the Canadian Cancer Society.

The publication costs of this article were defrayed in part by payment of page charges. This article must therefore be hereby marked "advertisement" in accordance with 18 USC section 1734 solely to indicate this fact.

\section{References}

Batsche, E., Muchardt, C., Behrens, J., Hurst, H.C., and Cremisi, C. 1998. RB and c-Myc activate expression of the E-cadherin gene in epithelial cells through interaction with transcription factor AP-2. Mol. Cell. Biol. 18: 3647-3658.

Bodner, M., Castrillo, J.L., Theill, L.E., Deerinck, T., Ellisman, M., and Karin, M. 1988. The pituitary-specific transcription factor GHF-1 is a homeobox-containing protein. Cell 55: 505-518.

Carreira, S., Dexter, T.J., Yavuzer, U., Easty, D.J., and Goding, C.R. 1998. Brachyury-related transcription factor Tbx2 and repression of the melanocyte-specific TRP-1 promoter. Mol. Cell. Biol. 18: 5099-5108.

Daikoku, S., Chikamori, M., Adachi, T., and Maki, Y. 1982. Effect of the basal diencephalon on the development of Rathke's pouch in rats: A study in combined organ cultures. Dev. Biol. 90: 198-202.

Dasen, J.S., O'Connell, S.M., Flynn, S.E., Treier, M., Gleiberman, AS, Szeto, D.P., Hooshmand, F., Aggarwal, A.K., and Rosenfeld, M.G. 1999. Reciprocal interactions of Pit1 and GATA2 mediate signaling gradient-induced determination of pituitary cell types. Cell 97: 587-598.
Dolle, P., Castrillo, J.L., Theill, L.E., Deerinck, T., Ellisman, M., and Karin, M. 1990. Expression of GHF-1 protein in mouse pituitaries correlates both temporally and spatially with the onset of growth hormone gene activity. Cell 60: 809-820.

Drouin, J., Sun, Y.L., and Nemer, M. 1990. Regulatory elements of the pro-opiomelanocortin gene. Pituitary specificity and glucocorticoid repression. Trends Endocrinol. Metab. 1: 219-225.

Ericson, J., Norlin, S., Jessell, T.M., and Edlund, T. 1998. Integrated FGF and BMP signaling controls the progression of progenitor cell differentiation and the emergence of pattern in the embryonic anterior pituitary. Development 125: 1005-1015.

Gage, P.J., Suh, H.Y., and Camper, S.A. 1999. Dosage requirement of Pitx2 for development of multiple organs. Development 126: 4643-4651.

Halvorson, L.M., Kaiser, U.B., and Chin, W.W. 1996. Stimulation of luteinizing hormone $\beta$ gene promoter activity by the orphan nuclear receptor, steroidogenic factor-1. I. Biol. Chem. 271: 6645-6650.

Halvorson, L.M., Ito, M., Jameson, J.L., and Chin, W.W. 1998. Steroidogenic factor- 1 and early growth response protein 1 act through two composite DNA binding sites to regulate luteinizing hormone $\beta$-subunit gene expression. J. Biol. Chem. 273: 14712-14720.

He, M., Wen, L., Campbell, C.E., Wu, J.Y., and Rao, Y. 1999. Transcription repression by Xenopus ET and its human ortholog TBX3, a gene involved in ulnar-mammary syndrome. Proc. Natl. Acad. Sci. 96: 10212-10217.

Ingraham, H.A., Chen, R., Mangalam, H.J., Elsholtz, H.P., Flynn, S.E., Lin, C.R., Simmons, D.M., Swanson, L., and Rosenfeld, M.G. 1988. A tissue-specific transcription factor containing a homeodomain specifies a pituitary phenotype. Cell 55: 519-529.

Ingraham, H.A., Lala, D.S., Ikeda, Y., Luo, X., Shen, W.H., Nachtigal, M.W., Abbud, R., Nilson, J.H., and Parker, K.L. 1994. The nuclear receptor steroidogenic factor 1 acts at multiple levels of the reproductive axis. Genes \& Dev. 8: 2302-2312.

Lamolet, B., Pulichino, A.M., Lamonerie, T., Gauthier, Y., Brue, T., Enjalbert, A., and Drouin, J. 2001. A pituitary cell-restricted T-box factor, Tpit, activates POMC transcription in cooperation with Pitx homeoproteins. Cell 104: 849-859.

Lanctôt, C., Lamolet, B., and Drouin, J. 1997. The bicoid-related homeoprotein Ptxl defines the most anterior domain of the embryo and differentiates posterior from anterior lateral mesoderm. Development 124: 2807-2817.

Lanctôt, C., Moreau, A., Chamberland, M., Tremblay, M.L., and Drouin, J. 1999. Hindlimb patterning and mandible development require the Ptx1 gene. Development 126: 1805-1810.

Lin, C.R., Kioussi, C., O'Connell, S., Briata, P., Szeto, D., Liu, R., Izpisua Belmonte, J.C., and Rosenfeld, M.G. 1999. Pitx2 regulates lung asymmetry, cardiac positioning and pituitary and tooth morphegenesis. Nature 401: 279-282.

Lin, S.C., Li, S., Drolet, D.W., and Rosenfeld, M.G. 1994. Pituitary ontogeny of the Snell dwarf mouse reveals Pit-1-independent and Pit-1-dependent origins of the thyrotrope. Development 120: 515-522.

Nissen, R.M. and Yamamoto, K.R. 2000. The glucocorticoid receptor inhibits NFкB by interfering with serine-2 phosphorylation of the RNA polymerase II carboxy-terminal domain. Genes \& Dev. 14: 2314-2329.

Parker, K.L. and Schimmer, B.P. 1997. Steroidogenic factor 1: A key determinant of endocrine development and function. Endocr. Rev. 18: 361-377.

Philips, A., Maira, M.H., Mullick, A., Chamberland, M., Lesage, S., Hugo, P., and Drouin, J. 1997. Antagonism between 
Nur77 and glucocorticoid receptor for control of transcription. Mol. Cell. Biol. 17: 5952-5959.

Poulin, G., Turgeon, B., and Drouin, J. 1997. NeuroD1/BETA2 contributes to cell-specific transcription of the POMC gene. Mol. Cell. Biol. 17: 6673-6682.

Poulin, G., Lebel, M., Chamberland, M., Paradis, F.W., and Drouin, J. 2000. Specific protein-protein interaction between basic Helix-Loop-Helix transcription factors and homeoproteins of the Pitx family. Mol. Cell. Biol. 20: 48264837.

Pulichino, A.-M., Vallette-Kasic, S., Couture, C., Gauthier, Y., Brue, T., David, M., Malpuech, G., Deal, C., Van Vliet, G., De Vroede, M., et al. 2003. Human and mouse TPIT gene mutations cause early onset pituitary ACTH deficiency. Genes \& Dev. (this issue).

Ray, A. and Prefontaine, K.E. 1994. Physical association and functional antagonism between the p65 subunit of transcription factor NF-к B and the glucocorticoid receptor. Proc. Nat1. Acad. Sci. 91: 752-756.

Rogatsky, I., Zarember, K.A., and Yamamoto, K.R. 2001. Factor recruitment and TIF2/GRIP1 corepressor activity at a collagenase- 3 response element that mediates regulation by phorbol esters and hormones. EMBO J. 20: 6071-6083.

Scheinman, R.I., Gualberto, A., Jewell, C.M., Cidlowski, J.A., and Baldwin Jr., A.S. 1995. Characterization of mechanisms involved in transrepression of NF- $\mathrm{B}$ B by activated glucocorticoid receptors. Mol. Cell. Biol. 15: 943-953.

Sheng, H.Z. and Westphal, H. 1999. Early steps in pituitary organogenesis. Trends Genet. 15: 236-240.

Sheng, H.Z., Zhadanov, A.B., Mosinger, B., Fujii, T., Bertuzzi, S., Grinberg, A., Lee, E.J., Huang, S.P., Mahon, K.A., and Westphal, H. 1996. Specification of pituitary cell lineages by the LIM homeobox gene Lhx3. Science 272: 1004-1007.

Sornson, M.W., Wu, W., Dasen, J.S., Flynn, S.E., Norman, D.J., O'Connell, S.M., Gukovsky, I., Carriere, C., Ryan, A.K., Miller, A.P., et al. 1996. Pituitary lineage determination by the Prophet of Pit-1 homeodomain factor defective in Ames dwarfism. Nature 384: 327-333.

Stallings, N.R., Hanley, N.A., Majdic, G., Zhao, L., Bakke, M., and Parker, K.L. 2002. Development of a transgenic green fluorescent protein lineage marker for steroidogenic factorMol. Endocrinol. 16: 2360-2370.

Steger, D.J., Hecht, J.H., and Mellon, P.L. 1994. GATA-binding proteins regulate the human gonadotropin $\alpha$-subunit gene in the placenta and pituitary gland. Mol. Cell. Biol. 14: 55925602.

Takuma, N., Sheng, H.Z., Furuta, Y., Ward, J.M., Sharma, K., Hogan, B.L., Pfaff, S.L., Westphal, H., Kimura, S., and Mahon, K.A. 1998. Formation of Rathke's pouch requires dual induction from the diencephalon. Development 125: 48354840.

Treier, M., Gleiberman, A.S., O'Connell, S.M., Szeto, D.P., McMahon, J.A., McMahon, A.P., and Rosenfeld, M.G. 1998. Multistep signaling requirements for pituitary organogenesis in vivo. Genes \& Dev. 12: 1691-1704.

Treier, M., O'Connell, S., Gleiberman, A., Price, J., Szeto, D.P., Burgess, R., Chuang, P.T., McMahon, A.P., and Rosenfeld, M.G. 2001. Hedgehog signaling is required for pituitary gland development. Development 128: 377-386.

Tremblay, J.J. and Drouin, J. 1999. Egr-1 is a downstream effector of GnRH and synergizes by direct interaction with Ptx1 and SF-1 to enhance luteinizing hormone $\beta$ gene transcription. Mol. Cell. Biol. 19: 2567-2576.

Tremblay, J.J., Lanctôt, C., and Drouin, J. 1998. The pan-pituitary activator of transcription, Ptx-1 (pituitary homeobox1), acts in synergy with SF-1 and Pit1 and is an upstream regu- lator of the Lim-homeodomain gene Lim3/Lhx3. Mol. Endocrinol. 12: 428-441.

Tremblay, J.J., Marcil, A., Gauthier, Y., and Drouin, J. 1999. Ptxl regulates SF-1 activity by an interaction that mimics the role of the ligand-binding domain. EMBO J. 18:34313441.

Yang-Yen, H.F., Chambard, J.C., Sun, Y.L., Smeal, T., Schmidt, T.J., Drouin, J., and Karin, M. 1990. Transcriptional interference between c-jun and the glucocorticoid receptor: Mutual inhibition of DNA binding due to direct protein-protein interaction. Cell 62: 1205-1215.

Zhao, L., Bakke, M., Krimkevich, Y., Cushman, L.J., Parlow, A.F., Camper, S.A., and Parker, K.L. 2001. Steroidogenic factor 1 (SF1) is essential for pituitary gonadotrope function. Development 128: 147-154. 


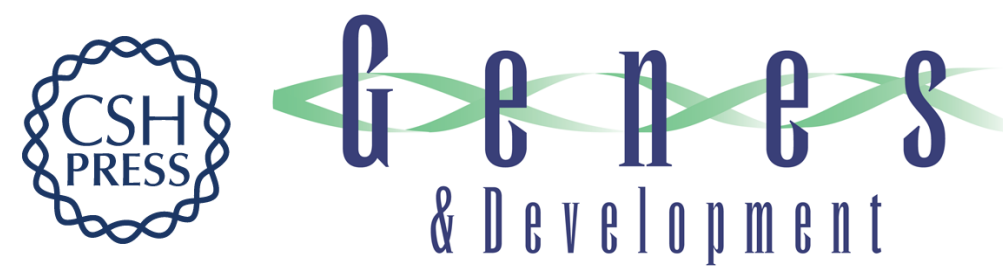

\section{Tpit determines alternate fates during pituitary cell differentiation}

Anne-Marie Pulichino, Sophie Vallette-Kasic, Judy Peih-Ying Tsai, et al.

Genes Dev. 2003, 17:

Access the most recent version at doi:10.1101/gad.1065703

References This article cites 39 articles, 26 of which can be accessed free at: http://genesdev.cshlp.org/content/17/6/738.full.html\#ref-list-1

License

Email Alerting Receive free email alerts when new articles cite this article - sign up in the box at the top Service right corner of the article or click here.

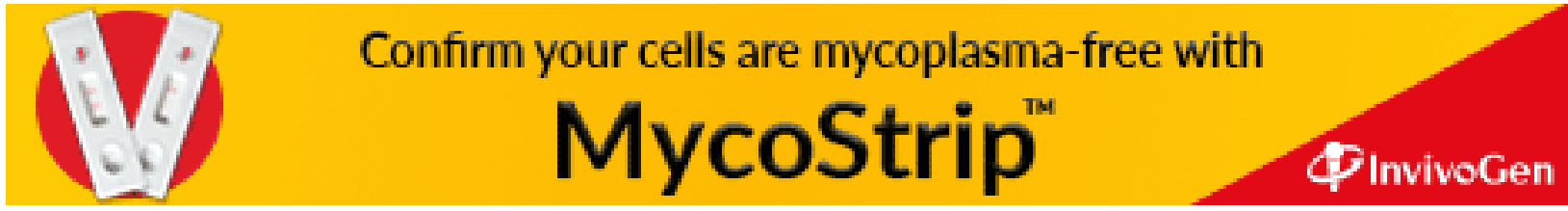

